discussion papers

FS IV $02-09$

Contribution to Productivity or Pork Barrel? The Two Faces of Infrastructure Investment

Olivier Cadot*

Lars-Hendrik Röller **

Andreas Stephan ***

* HEC - Ecole des Hautes Etudes Commerciales de Lausanne

** Wissenschaftszentrum Berlin für Sozialforschung

*** Deutsches Institut für Wirtschaftsforschung

May 2002

ISSN Nr. 0722 - 6748

Forschungsschwerpunkt

Markt und politische Ökonomie

Research Area

Markets and Political Economy 
Zitierweise/Citation:

Olivier Cadot, Lars-Hendrik Röller and Andreas Stephan, Contribution to Productivity or Pork Barrel? The Two Faces of Infrastructure Investment, Discussion Paper FS IV 02-09, Wissenschaftszentrum Berlin, 2002.

Wissenschaftszentrum Berlin für Sozialforschung gGmbH, Reichpietschufer 50, 10785 Berlin, Germany, Tel. (030) 25491 - 0 Internet: www.wz-berlin.de 


\section{ABSTRACT \\ Contribution to Productivity or Pork Barrel? The Two Faces of Infrastructure Investment*}

by Olivier Cadot, Lars-Hendrik Röller and Andreas Stephan

This paper proposes a simultaneous-equation approach to the estimation of the contribution of transport infrastructure accumulation to regional growth. We model explicitly the political-economy process driving infrastructure investments; in doing so, we eliminate a potential source of bias in production-function estimates and generate testable hypotheses on the forces that shape infrastructure policy. Our empirical findings on a panel of France's regions over 1985-92 suggest that electoral concerns and influence activities were, indeed, significant determinants of the crossregional allocation of transportation infrastructure investments. By contrast,we find little evidence of concern for the maximization of economic returns to infrastructure spending, even after controlling for pork-barrel.

Keywords: Growth, Infrastructure, Political Economy, Lobbying, France

JEL Classification: D72, D78, 040

* This research was produced as part of a CEPR research network on The Evolution of Market Structure in Network Industries, funded by the European Commission under the Training and Mobility of Researchers Program (contract \# ERBFMRXCT980203). Röller and Stephan acknowledge financial support from the Deutsche Forschungsgemeinschaft (DFG) for this project. Part of this paper was written while Cadot was at INSEAD and was supported under grant 20102227R. We are grateful to Patrick Legros, Guillaume Rocheteau, and participants at conferences and seminars at CIRANO, DELTA, Nova University in Lisbon, the Universitat Autonoma de Barcelona, the University of Geneva and the Young Economist Meeting in Amsterdam for helpful comments, and to Bernard Fritsch for kindly supplying the private capital stock data. Special thanks to Jose Anson and Pierre Blime for superb research assistance. 
ZUSAMMENFASSUNG

Beitrag zur Produktivität oder Pork-barrel? Die zwei Seiten von Infrastrukturinvestitionen

In dieser Untersuchung wird ein simultanes Gleichungssystem zur Schätzung des Beitrags von Verkehrsinfrastrukturinvestitionen zu regionalem Wachstum verwendet. Es wird explizit der politische Prozeß modelliert, der Infrastrukturinvestitionen determiniert; dadurch wird eine mögliche Ursache einer verzerrten Parameterschätzung vermieden, die eintreten kann, wenn Produktionsfunktionen einzeln geschätzt werden. Gleichzeitig fließen in das Modell weitere empirisch überprüfbare Hypothesen über die Determinanten von Infrastrukturpolitik ein. Die empirischen Ergebnisse für einen Paneldatensatz mit 21 französischen Regionen im Zeitraum 1985-1991 zeigen, daß unterstützende Aktivitäten in der Tat einen signifikanten Einfluß auf die regionale Allokation von Verkehrsinfrastrukturinvestitionen haben. Darüber hinaus werden nur wenig empirische Hinweise dafür gefunden, daß auch erwartete Produktivitätseffekte von Infrastruktur bei der regionalen Allokation in Frankreich von Bedeutung sind. 


\section{Introduction}

If there is little doubt that investment in public infrastructure capital is a necessary condition for long-run growth in industrial countries and, a fortiori, in developing ones, how much infrastructure investment actually contributes to growth is still, in spite of a longstanding debate, a largely unsettled question. Disagreement over the magnitudes involved has persisted in spite of a massive amount of research sparked by the influential work of Aschauer (1989a, b). Using aggregate data for the US between 1949 and 1985, Aschauer found that the elasticity of output to a broad measure of public infrastructure capital was significant and quantitatively very large. At a time (long gone) of concern about the slowdown in US productivity growth, these findings suggested that a decline in the rate of public-capital accumulation was "a potential new culprit" (Munnell, 1990a, p.3). Although economists are now as busy trying to explain the productivity pickup as they were trying to explain its slowdown a decade ago, it is still of interest, irrespective of what productivity does, to try to understand the relationship between growth and public infrastructure investments. Moreover, if the debates originates, both empirically and intellectually, in the United States, it is nevertheless particularly relevant in developing countries.

Early studies of the link between public capital and growth were fraught with logical and econometric difficulties, the most important of which are discussed in Gramlich's 1994 review essay. Some authors argued that the correlation between productivity growth and public-capital accumulation could be spurrious because relevant variables were omitted, while others pointed out that the direction of causation was unclear (see Eisner, 1991; Tatom, 1993; or Holtz-Eakin, 1994). For instance, Holtz-Eakin remarked that "it is tempting to infer a causal relationship from public-sector capital to productivity, but the evidence does not justify this step. It is just as easy to imagine the reverse scenario in which deteriorating economic conditions reduce capital-stock growth" (1994, p. 12). Disagreement over the meaning of elasticity estimates was not limited to time-series studies. Holtz-Eakin (1988), Munnell (1990a,b) and Garcia-Milà (1992) also found positive elasticities of output to public capital using panel data at the state level (although their estimates were smaller than Aschauer's) but state-level evidence was vulnerable to similar criticism: quoting again Holtz-Eakin (1994, p. 13), “[b]ecause more prosperous states are likely to spend more on public capital, there will be a positive cor- 
relation between the state-specific effects and public sector capital. This should not be confused, however, with the notion that greater public capital leads a state to be more productive". Holtz-Eakin's own approach consisted of introducing fixed effects in the specification of the error structure in order to control for unobserved state characteristics. But, as he himself remarked (p.13), "in doing so the investigator ignores the information from cross-state variation in the variables", which is of course unfortunate given that in a panel of short duration a substantial part of the information comes, precisely, from the data's cross-sectional variation.

This paper addresses the endogeneity issue directly, by using simultaneous-equation estimation (see Hulten, 1995 for a discussion; see also Tatom, 1993). A few authors followed this approach, e.g. Duffy-Deno and Eberts (1991) or Flores de Frutos and Pereira (1993), and nevertheless found significant elasticities of output to infrastructure capital. But the key question, if one believes that the endogeneity issue matters, is how infrastructure investment decisions should be modelled. Clearly, the "second equation" should be grounded in a theory of how public infrastructure investment decisions are made. Indeed, Gramlich (1994) rightly points out that the primary interest of the infrastructure debate is not so much in the battle over elasticity estimates as in the implied policy debate. In his words, "rather than asking whether there is a shortage, it seems more helpful to ask what, if any, policies should be changed" (p. 1190). This type of normative question presupposes that institutions and policy choices are designed to maximize social welfare. But are they? A growing literature, at the frontier of economics and political science, views economic-policy decisions as resulting from the maximization by incumbent politicians of objective functions that may depart from social welfare, under constraints that are primarily political (see Dixit, 1996; Drazen, 2000; Persson and Tabellini, 2000; or Grossman and Helpman, 2001, for recent surveys). This literature approaches from a positive angle questions that used to be the realm of the normative, taking policy variables to be endogenous rather than control variables. Ultimately, normative considerations are likely to reappear, e.g. in the form of prescriptions in favor of rules or institutions mitigating policy capture by special interests; but the literature's key message is that irrespective of what politicians ought to do, economists need to understand what they actually do and why. For instance, if public infrastructure investment decisions are influenced by pork-barrel politics, pork-barrel politics should be part of the model. We believe that this provides a useful starting point for a discussion of what 
the "second equation" should be.

In this perspective, the present paper is a contribution to bridging the gap between the infrastructure and political-economics literatures (see also, inter alia, Crain and Oakley, 1995, Besley and Coate, 1998, or Lizzeri and Persico, 2001; on ownership issues, see Besley and Ghatak, 2001). A number of theoretical approaches are available to model the relevant decision-making processes, depending upon the institutional context (e.g. direct vs. indirect democracy, legislature involvement vs. delegation to executive agencies) and upon behavioral assumptions (e.g. partisan vs. opportunitistic politicians). As infrastructure investment is not an area in which partisanship creates strong dividing lines, we have chosen to use a model with office-motivated politicians and probabilistic voting, to which we add influence activites. The model is then tested on a French data set. Using French data has both benefits and costs. The primary benefit is that widespread accusations of corruption and pork barrel, in the press and elsewhere, ${ }^{1}$ give a fairly strong prior in favor of their existence. The cost is the benefit's mirror image namely, lack of transparency about contributions from lobbies which are, unlike in the US, neither published nor even officially recorded, and consequently cannot be observed directly.

In order to proxy for lobbying, we start by assuming that firms have sunk investments giving them vested interests in the quality of the infrastructure in regions where they have production units ("establishments"). We also posit that a firm with a large establishment in a given region should be expected to lobby harder than other firms for the maintenance and upgrading of that region's infrastructure, for three reasons. First, large establishments produce, on average, for more distant markets (as higher volumes must be absorbed by wider geographical areas); as a result, they use highways and railways more intensively than others and are consequently more concerned about their maintenance and upgrading. Second, large establishments are typically owned by firms with headquarters in Paris; those firms are likely to be in a better position to effectively reinforce local lobbying by direct access to national policy-makers. Third, although we do not deal explicitly with collective-action problems in mobilizing local political resources, such problems are likely to be easier overcome for a few firms with large stakes, such as Michelin in Auvergne or Citroën in Bretagne, than for a host of small or medium-sized

\footnotetext{
${ }^{1}$ See, inter alia, de Closets (1992), Mény (1992), Etchegoyen (1995), Lorenzi (1995), or “100 lobbies qui font la loi en France", Capital, June 18, 1998.
} 
local firms. For all these reasons, we take the number of large establishments in a region as a proxy for the intensity of that region's lobbying for transportation infrastructure investment.

Although this indirect approach by itself may not be powerful enough to provide unambiguous evidence of pork barrel, the combination of voting with lobbying in the model generates a number of testable results, including, as is typical in voting models, a disproportionate share of favors going to swing voters. The importance of the latter in each region is proxied with two alternative variables. The first is the difference, in absolute value, between the scores of the right-wing and left-wing coalitions in recent elections. This is not really a 'swing voter' variable, but rather a measure of how heated the electoral race was, which is slightly different but nevertheless also conducive of political favors. The second is the combined score of Jean-Marie Le Pen's Front National and a fringe hunters' party called Chasse, pêche, nature et tradition. The rationale for taking the Front National as a measure of swing voters is as follows. Although the party's platform was clearly at the extreme right wing of the political spectrum, ${ }^{2}$ a number of observers ${ }^{3}$ have noted the heterogeneity of its constituency, which included e.g. disgruntled communist voters attracted by Le Pen's populist anti-establishment themes as much as by his right-wing ones (law and order and social conservatism). Similarly, the hunters' party, important in the Southwest, is essentially anti-Brussels and anti-environmentalist. During our sample period, the Socialists had not yet concluded any alliance with the Green party, and had in fact fairly bad relations with Greenpeace and environmentalist groups. Thus, the hunters-vs.-environmentalists issue cut across the left-wing/rightwing divide, and using pork-barrel politics to try and woo hunters or Le Pen voters made sense for either right-wing or left-wing governments.

Indeed, the data suggests that this is precisely what they did; in fact, both measures of pork barrel (lobbying- and vote-based) tell essentially the same story - that pork barrel matters. Although the vote-based measure provides more direct evidence of this, we believe that our estimates of electoral and lobbying influences should be seen as complementary rather than as a test of one hypothesis against the other. We also find that over our sample period, during which left-wing parties were in power for five years and

\footnotetext{
${ }^{2}$ The Front National, created in 1972, was an extreme-right wing, anti-immigrant party. Led by its flamboyant leader Jean-Marie Le Pen, it reached the peak of its popularity in the 1990s, collapsing thereafter under the effect of internal rivalries.

${ }^{3}$ See for instance Mayer and Perrineau (1996), Chiche and Rey (1995), Franceries (1993).
} 
right-wing ones for two, the French government did not seem to be significantly concerned with the maximization of economic returns from infrastructure spending. This result, which is robust to changes in the functional form of the government's objective function, reinforces our conclusion that pork-barrel considerations were importantperhaps primary-policy drivers in the sample period. However, the simultaneity bias from estimating a production function alone is negligible, as single-equation elasticity estimates are almost identical to those obtained by simultaneous estimation of both equations. The reason is that infrastructure stocks are too large relative to investments for feedback influences to be felt over a sample period of less than a decade.

The remainder of this paper is organized as follows. In section 2, we state general conditions for the efficient provision of a public input and build up, in several steps, a dynamic model suggestive of how electoral concerns and influence activities can bias infrastructure investment decisions. In section 3, we report the results of empirical testing of the model's hypotheses on a French data set. Section 4 concludes.

\section{Theory}

Basic results on the optimal provision of public inputs were derived by Kaizuka (1965), Sandmo (1972), and Negishi (1973). We briefly review these results in the following section in order to provide a benchmark against which inefficiencies arising from influence activities can be assessed.

\subsection{Static problem}

\subsubsection{Efficient provision of a public input}

Consider an economy producing $m+1$ final goods for consumption, with technologies $f^{i}\left(k_{i}, \ell_{i}, x\right)$, for $i=0, \ldots, m$, where $k_{i}$ and $\ell_{i}$ are respectively the amounts of capital and labor used up in the production of good $i$ and $x$ is a pure public input. Following Negishi (1973), we take the latter to be of the "unpaid input" type, meaning that the function $f^{i}$ is linearly homogenous in $k_{i}, \ell_{i}$ and $x .{ }^{4}$ When such is the case, owners of capital, which are residual claimants, appropriate the rents generated by the public input if the latter is

\footnotetext{
${ }^{4}$ The alternative formulation is to assume that the production function is linearly homogenous in $k_{i}$ and $\ell_{i}$ alone and has increasing returns in all factors including $x$. This alternative formulation is generally seen as appropriate for publicly-provided $R \& D$, whereas the classical example of the former formulation is, according to Sandmo (1972) and Negishi (1973), transportation infrastructure.
} 
not priced at the value of its marginal product. This is a source of potential inefficiency in capital-allocation decisions; but for simplicity we limit the analysis to a short-run case where capital is fixed; the theory can be easily extended to a long-run case.

Let the public input be produced with labor only according to a technology $g\left(\ell_{x}\right)$, and let $\ell_{x}+\sum_{i=0}^{m} \ell_{i}=1$ be the economy's total endowment of labor. The social utility function is quasilinear (necessary conditions for the aggregation of individual preferences into a social utility function are assumed to hold), with $U\left(c_{0}, \ldots, c_{m}\right)=$ $c_{0}+\sum_{i=1}^{m} u\left(c_{i}\right)$ for some increasing and concave function $u$. Given this, the problem of a social planner is: ${ }^{5}$

$$
\begin{aligned}
& \max _{\ell_{0}, \ldots, \ell_{m}, \ell_{x}} c_{0}+\sum_{i=1}^{m} u\left(c_{i}\right) \\
& \text { s.t. } \\
& c_{i}=f^{i}\left(k_{i}, \ell_{i}, x\right), \quad i=0, \ldots, m, \\
& x=g\left(\ell_{x}\right), \\
& 1=\ell_{x}+\sum_{i=0}^{m} \ell_{i} .
\end{aligned}
$$

Letting subscripts denote partial derivatives (so $f_{\ell}^{i}=\partial f^{i} / \partial \ell_{i}$ and $f_{x}^{i}=\partial f^{i} / \partial x$ ), solving (1) and rearranging the resulting first-order conditions gives the basic condition for the efficient provision of $x$ (Kaizuka, 1965):

$$
\sum_{i=0}^{m} \frac{f_{x}^{i}}{f_{\ell}^{i}}=\frac{1}{g^{\prime}} .
$$

This efficiency condition can also be derived from the maximization of firm profits. Let good 1 be the numeraire, $p_{i}$ the price of good $i$ in terms of good 1 , and $w$ the wage rate, and fix all prices and the wage rate at the levels obtained implicitly from the solution of problem (1). Suppose that, at these exogenously given prices and wage, competitive firms make profit-maximizing decisions contingent on $x$; let also $h$ be the inverse function of $g$ so that $\ell_{x}=h(x)$. A government maximizing firm profits by choice

\footnotetext{
${ }^{5}$ Transportation infrastructure is used as an input not only by firms, but also by households; so a complete statement of the problem should include a household production function. We will abstract from such considerations and treat transportation infrastructure as a "pure input".
} 
of $x$ will solve:

$$
\begin{aligned}
& \max _{x} f^{0}\left(k_{0}, \ell_{0}, x\right)+\sum_{i=1}^{m} p_{i} f^{i}\left(k_{i}, \ell_{i}, x\right)-w \sum_{i=0}^{m} \ell_{i}-w h(x) \\
& \text { s.t } \\
& f_{\ell}^{0}=p_{1} f_{\ell}^{1}=\ldots=p_{i} f_{\ell}^{i}=\ldots=w .
\end{aligned}
$$

It is easily checked that the solution of (3) is

$$
\sum_{i=0}^{m} \frac{f_{x}^{i}}{f_{\ell}^{i}}=h^{\prime}=\frac{1}{g^{\prime}}
$$

and consequently yields the same level of provision of $x$ as (2). Although straightforward, this result is important for our purposes. To see why, consider a simple influenceactivity game in which firms offer monetary contributions to an incumbent politician in exchange for the public input's provision, and suppose that the incumbent maximizes the sum of those contributions net of the input's cost. If, at the margin, contributions reflect the willingness of firms to pay for the input, the influence-activity game's unique equilibrium is the solution to (3). In other words, if $L^{i}(x)$ is industry $i$ 's offer of a monetary contribution to the government and $\pi^{i}=p_{i} f^{i}\left(k_{i}, \ell_{i}, x\right)-w \ell_{i}$ (with $p_{0}=1$ ) is its profits, whenever $\partial L^{i} / \partial x=\partial \pi^{i} / \partial x$, a government maximizing $\sum_{i} L^{i}(x)-w h(x)$ will solve (3) and consequently provide $x$ according to (2). Thus, influence activities by themselves do not imply inefficient provision of the public input.

This result-namely, that the existence of influence activities is not a sufficient condition for an inefficient policy outcome-is simply a restatement of Bernheim and Whinston's (1986a) result according to which, if influence activities can be represented as a "menu auction" and if special-interest groups bid for policy according to their marginal valuation, the resulting "truthful" equilibrium is Pareto-efficient (see also Bernheim and Whinston, 1986b, for parallel efficiency results in a common-agency context). This result also appears in a trade-policy context in Grossman and Helpman (1994) who show that in a small open economy, if all agents are represented in one lobby or another, the resulting equilibrium is free trade (see also Becker, 1983 and Wittman, 1983 for arguments in the same spirit). We now turn to conditions under which influence activities do lead to inefficient policy choices.

\subsubsection{Influence activities}

Inefficiencies appear if some firms do not have access to the bidding process. For instance, small firms may keep out of lobbying because it entails an entry fee that is pro- 
hibitive for them. Suppose that the incumbent government maximizes a convex combination of social utility $U\left(\right.$.) and a monetary contribution $L^{k}(x)$ from some non-numeraire industry $k$. Again, the economy is in a competitive equilibrium as far as consumption and the allocation of labor across industries are concerned, the government's only problem being the provision of the public input $x$. The resource constraint is represented by an increasing and convex function $\phi(x)$. Letting $a$ be the weight on social utility, the government now solves

$$
\begin{aligned}
& \max _{x}(1-a) L^{k}(x)+a\left[c_{0}+\sum_{i=1}^{m} u\left(c_{i}\right)\right]-\phi(x) \\
& \text { s.t. } \\
& c_{i}=f^{i}\left(k_{i}, \ell_{i}, x\right), \quad i=0, \ldots, m, \\
& f_{\ell}^{0}=p_{1} f_{\ell}^{1}=\ldots=p_{m} f_{\ell}^{m}=w, \\
& u^{\prime}=p_{i} \quad \forall i=1, \ldots, m, \\
& L^{k \prime}(x)=\partial \pi^{k} / \partial x=p_{k} f_{x}^{k},
\end{aligned}
$$

with first-order condition

$$
(1-a) p_{k} f_{x}^{k}+a\left(f_{x}^{0}+u^{\prime} \sum_{i=1}^{m} f_{x}^{i}\right)-\phi^{\prime}=0 .
$$

Suppose again that, when evaluated at the socially optimal level of $x, \phi^{\prime}(x)=w h^{\prime}(x)$, where $w$ is the wage rate obtained in the solution of (1). After substitution of the relevant constraints, (5) becomes

$$
\frac{f_{x}^{k}}{f_{\ell}^{k}}+a \sum_{i \neq k} \frac{f_{x}^{i}}{f_{\ell}^{i}}=h^{\prime} .
$$

Thus, efficiency condition (2) is now violated; as the left-hand side of (6) is a decreasing function of $x$ whereas its right-hand side is an increasing one, the public input is underprovided in (6) compared to (2). However, underprovision follows from the choice of a convex combination of social utility and industry $k^{\prime}$ s contribution in the objective function; non-convex linear combinations could yield overprovision.

Given that (6)'s departure from optimality comes from the fact that sector $k$ and only sector $k$ lobbies, it can be eliminated in two ways. First, the distortion shrinks as $a$ increases; in the limit, when $a=1,(6)$ reduces to (2). That is, the departure from optimality disappears if the government's valuation of sector $k^{\prime}$ s contribution goes to zero. Second, if all industries lobby, (6) reduces to (2) irrespective of the value of $a$ in $[0,1]$, because by choosing $x$ to maximize a convex combination of social utility and the profits of competitive firms, the government in effect solves twice the same problem. 


\subsection{Dynamic problem}

The approach outlined in the previous section, which is now widely used in the literature on endogenous trade policy, is static. If dynamic considerations may not always be crucial as far as trade-policy issues are concerned, they are less easily dismissed in a public-infrastructure investment context. Indeed, Besley and Coate (1998) showed how infrastructure projects that are potential Pareto improvements (in a sense that they make precise) may not be undertaken in a dynamic equilibrium because of uncertainty over electoral outcomes. For instance, a project may not be undertaken if it is expected to change the preferences of some voter groups in a way that is unfavorable to the incumbent politician. Alternatively, a project that benefits directly only a fraction of the population may not be undertaken if politicians representing the non-beneficiary constituency anticipate that they will not control the redistribution instruments that would allow the project's benefits to be shared in the future. We do not consider this type of issue, but we use a dynamic, infinite-horizon framework to analyze our public-investment policy problem.

In the treatment that follows, we also modify the government's objective function. Instead of a linear combination of social welfare and contributions from lobbies, we assume that candidates maximize expected rents, i.e. the product of the rents from being in office times the probability of getting there. As in Besley and Coate (2001), bribes from lobbies constitute part of the rents that motivate individuals to win elections. However, unlike in their "citizen-candidate" model, we assume two exogenously designated, purely office-motivated candidates, and probabilistic voting with some exogenous preference (incumbency advantage or ideological bias). This setting, which ensures equilibrium existence, rules out a discussion of endogenous entry or strategic voting, but it nevertheless generates results that are strong enough to be tested in a meaningful way against the data, as we will see later.

\subsubsection{Efficient provision}

Let the law of motion of the infrastructure stock $x_{t}$ be

$$
x_{t+1}=(1-\delta) x_{t}+z_{t}
$$

where $z_{t}$ is the flow of gross infrastructure investments and $\delta$ is depreciation. The population is a continuum of individuals of size one, and consumers have identical and 
quasilinear preferences over two goods: good zero (the numeraire) and good one. Perperiod utility is thus

$$
U\left(c_{t}^{0}, c_{t}^{1}\right)=c_{t}^{0}+u\left(c_{t}^{1}\right)
$$

and with an infinite horizon, intertemporal utility is $\sum_{t=0}^{\infty} \beta^{t} U\left(c_{t}^{0}, c_{t}^{1}\right)$, where $\beta=1 /(1+$ $r)$ is a discount factor.

Goods zero and one are produced by combining labor with the infrastructure according to technologies $f^{0}\left(x_{t}, \ell_{t}\right)$ and $f^{1}\left(x_{t}, 1-\ell_{t}\right)$ respectively. Finally, infrastructure investments cost $\mu z_{t}{ }^{2} / 2$, for some parameter $\mu$. The social planner's problem is thus

$$
\max _{\left\{\ell_{t}, x_{t}\right\}} \sum_{t=0}^{\infty} \beta^{t} U\left(c_{t}^{0}, c_{t}^{1}\right)=\sum_{t=0}^{\infty} \beta^{t}\left\{f^{0}\left(x_{t}, \ell_{t}\right)+u\left[f^{1}\left(x_{t}, 1-\ell_{t}\right)\right]-\mu z_{t}{ }^{2} / 2\right\}
$$

subject to (7). This is a standard capital-accumulation problem whose Euler equation is

$$
\mu z_{t}=\beta\left[f_{x}^{0}+u^{\prime} f_{x}^{1}+(1-\delta) \mu z_{t+1}\right] .
$$

Together with suitable initial and transversality conditions, (10) and (7) completely characterize the infrastructure stock's trajectory. It can be shown that, for positive values of $\delta$, the system has a saddle point, so that there is only one perfect-foresight trajectory for $x_{t}$. In the steady state, all variables are constant and

$$
z^{*}=\frac{\beta}{\mu[1-\beta(1-\delta)]}\left(f_{x}^{0}+u^{\prime} f_{x}^{1}\right)=\delta x^{*} .
$$

In order to compare (11) with the solution of the static welfare-maximization problem, suppose that $\mu=w$, where $w$ is the steady-state value of the equilibrium wage rate, which satisfies $w=f_{\ell}^{0}=p f_{\ell}^{1}$. Making use of the fact that $u^{\prime}\left(c^{1}\right)=p$, where $p$ is the steady-state value of good one's relative price and substituting and letting $\widetilde{\beta}=\beta /[1-$ $\beta(1-\delta)]$, we get

$$
z^{*}=\widetilde{\beta} \sum_{k=0,1} \frac{f_{x}^{k}}{f_{\ell}^{k}}
$$

Under quadratic investment costs, $z^{*}$ is just the marginal cost of infrastructure investments expressed in terms of labor; thus, the limit of the expression above as $\beta$ and $\delta$ tend to one (no discounting and full depreciation) is just the static solution (2).

\subsubsection{Electoral concerns}

We now want to assess how departures from the social optimum given by (11) can arise when decision-makers are exposed to electoral concerns and pressure from lobbies. A 
number of issues arise in this regard. First, according to what criteria do voters make their decisions? Second, who are the agents behind the pressure groups and why do they need, in democracy, to take specific action to make themselves heard?

Starting with the second question, in a model with heterogenous voters any group of individuals whose preferences differ from those of the median voter (in a Downsian model) or the average one (under probabilistic voting) qualifies as a "special interest". 6 In order to put things in a sharp light, we assume here that the lobby is made of specificfactor owners who are so few that they have measure zero in the voting population.

As to the first question, we will stop short of the complications of a full-fledged Ramsey model with consumers and firms optimizing intertemporally, and instead assume that individuals live only for one period (and have no intergenerational links), a period being also an electoral cycle. The only agent optimizing intertemporally is thus the government making infrastructure-investment decisions. Individuals vote probabilistically over candidates on the basis of the utility implications of their platform (what level they propose for $z_{t}$ ) for the current period.

In order to focus first on electoral concerns only, we suppose in this section that the special interest is 'silent'. There are now three sectors: sectors zero and one use the infrastructure, whereas sector two operates it. "Almost all" individuals are endowed with identical porfolios made of shares of sectors zero and one, whereas a small number of individuals (the lobby) are endowed with shares of sector two. Let $p_{t}$ be the price of good one in terms of good zero at time $t$. At the consumer's optimum, the marginal utility of income is unity, $u^{\prime}\left(c_{t}^{1}\right)=p_{t}$, and, letting $I_{t}$ be income at time $t, c_{t}^{0}=I_{t}-p_{t} c_{t}^{1}$. Individuals are at the same time workers, shareholders and taxpayers; therefore, the wage bill washes out of their income, which is the sum of profits in sectors zero and one. As before, sectors zero and one, both of which are competitive, use the infrastructure with technologies $f^{k}\left(x_{t}, \ell_{t}^{k}\right), k=0,1$, and sector two (the public utility) operates the infrastructure, charging to firms in sectors zero and one a rate $\widetilde{\omega}_{t}$. This rate may be regulated (more on this below); in order to keep things easily comparable with the previous section, we will assume that the cost of operating the infrastructure is nil, so that $\widetilde{\omega}_{t}$ is a pure rent accruing to the public-utility's owners. This rent is what motivates their lobbying on infrastructure investments: if they made no profits, the level of the infrastructure stock would be of no concern to them.

\footnotetext{
${ }^{6}$ On this, see Grossman and Helpman (2001).
} 
Finally, the state decides on and finances (out of taxes) infrastructure investments, with quadratic costs $w_{t} z_{t}^{2} / 2$. Profits gross of labor costs are thus

$$
\begin{aligned}
& \pi_{t}^{0}=f^{0}\left(x_{t}, \ell_{t}\right)-\widetilde{\omega}_{t} x_{t}, \\
& \pi_{t}^{1}=p_{t} f^{1}\left(x_{t}, 1-\ell_{t}\right)-\widetilde{\omega}_{t} x_{t} \text { and } \\
& \pi_{t}^{2}=2 \widetilde{\omega}_{t} x_{t},
\end{aligned}
$$

and the 'representative' voter's income after taxes (the term 'representative' is slightly abused here since we are excluding the owners of sector two) is

$$
I_{t}=\pi_{t}^{0}+\pi_{t}^{1}-\mu z_{t}^{2} / 2=f^{0}\left(x_{t}, \ell_{t}\right)+p_{t} f^{1}\left(x_{t}, 1-\ell_{t}\right)-2 \widetilde{\omega}_{t} x_{t}-\mu z_{t}^{2} / 2 .
$$

Substituting $I_{t}-p_{t} c_{t}^{1}$ for $c_{t}^{0}$ in (8) gives the representative voter's indirect utility function, namely

$$
v_{t}=f^{0}\left(x_{t}, \ell_{t}\right)+p_{t} f^{1}\left(x_{t}, 1-\ell_{t}\right)-2 \widetilde{\omega}_{t} x_{t}-\mu z_{t}^{2} / 2+u\left(c_{t}^{1}\right)-p_{t} c_{t}^{1},
$$

which can also be seen as the sum of income and consumer surplus.

In each period (electoral cycle) votes are cast as functions of the platforms proposed by two office-seeking candidates, $i$ and $j$, for the current period, and of a small, exogenous popularity factor $l / b$ in favor of $i$, where $b$ is a positive parameter. Voters are ex ante identical, but voting behaviour is affected by a random shock. Formally, let $v_{t}^{i}$ be the indirect utility of a representative voter under the platform offered by $i$; she casts a vote for $i$ at time $t$ if and only if

$$
v_{t}^{i}-v_{t}^{j}>\varepsilon-\iota / b
$$

where $\varepsilon$ is an i.i.d shock uniformly distributed over $[-1 / 2 b ; 1 / 2 b] .^{7}$ Letting $\phi_{t}^{i}$ denote the probability that a representative voter casts a vote for $i$ at $t$,

$$
\phi_{t}^{i}=\operatorname{prob}\left(\varepsilon<v_{t}^{i}-v_{t}^{j}+\iota / b\right)=\frac{v_{t}^{i}-v_{t}^{j}+\iota / b+1 / 2 b}{1 / b}=\frac{1}{2}+\iota+b\left(v_{t}^{i}-v_{t}^{j}\right) .
$$

Let $\rho$ be a fixed utility rent from being in office. Absent any lobbying, politician $i$, wishing to maximize her expected utility in each electoral cycle by choice of a sequence of platforms (i.e. by choice of a sequence $\left\{x_{t}^{i}\right\}$ of values of the infrastructure stock, or,

\footnotetext{
${ }^{7}$ In this, we follow Persson and Tabellini's (2000) treatment of probabilistic voting.
} 
equivalently, by choice of a sequence $\left\{z_{t}^{i}\right\}$ of infrastructure investments) solves the following dynamic program:

$$
\max _{\left\{x_{t}^{i}\right\}} \sum_{t=0}^{\infty} \beta^{t} \phi_{t}^{i} \rho=\rho \sum_{t=0}^{\infty} \beta^{t}\left[\frac{1}{2}+\iota+b\left(v_{t}^{i}-v_{t}^{j}\right)\right] .
$$

Using (13) to get an expression for $\partial v_{t}^{i} / \partial x_{t+1}^{i}$ and $\partial v_{t+1}^{i} / \partial x_{t+1}^{i}$ and simplifying, the Euler equation is:

$$
\mu z_{t}^{i}=\beta\left[\left(f_{x}^{0}+u^{\prime} f_{x}^{1}-2 \widetilde{\omega}_{t+1}\right)+(1-\delta) \mu z_{t+1}^{i}\right] .
$$

The system's dynamic properties are unchanged, and the steady-state value of $z$ announced (and implemented) by politician $i, z^{i}$, is defined implicitly by

$$
z^{i}=\frac{\widetilde{\beta}}{\mu}\left(f_{x}^{0}+u^{\prime} f_{x}^{1}-2 \widetilde{\omega}\right),
$$

where $\widetilde{\omega}$ is the steady-state value of $\widetilde{\omega}_{t}$. Comparing (16) with (12), it is apparent that the only distortion originates from positive pricing of access to the infrastructure, which reduces its steady-state provision. The reason is that the marginal profitability of infrastructure to its users is reduced by the price that they have to pay for it; this is reflected in the voting equilibrium ${ }^{8}$ through a lower eagerness of voters to invest in it and hence to reward politicians who propose to do so.

In sum, electoral concerns by themselves do not introduce distortions in the steadystate level of infrastructure; what does so is access pricing above the social optimum (here zero). However, this efficiency result ought to be interpreted cautiously. In a careful theoretical analysis of electoral incentives, Lizzeri and Persico (2001) show how the provision of public goods can, actually, be distorted by electoral concerns, depending upon precise institutional arrangements. One of the key differences between their analysis and ours is that in theirs, policymakers have access to two instruments: a public good and a redistribution instrument, the latter being more precisely "targetable" to particular interests than the former. So the main interest of (16) is to serve as a benchmark against which additional distortions due to influence activities can be assessed, rather than to establish an efficiency result that is likely to be of limited robustness.

\footnotetext{
${ }^{8}$ It is easily checked that politicians $i$ and $j$ offer the same platform in equilibrium, characterized by (16). Given that the shock $\varepsilon$ is centered on zero, equilibrium election probabilities are $\phi^{i}=1 / 2+\iota, \phi^{j}=1 / 2-\iota$.
} 


\subsubsection{Influence activities}

Suppose now that sector two, which operates the infrastructure, offers politician $i$, if he gets elected, a monetary contribution - a bribe - conditioned on the level of infrastructure investment, $L\left(x_{t}^{i}\right)$, with the "truthfulness" property that $L^{\prime}\left(x_{t}^{i}\right)=d \pi_{t}^{2} / d x_{t}^{i}=2 \widetilde{\omega}_{t}$. As the lobby acts as a principal vis-à-vis politician $i$, the function $L\left(x_{t}^{i}\right)$ is set so as to maximize (by setting adequate incentives) the joint surplus of the lobby and the incumbent and to leave the incumbent on his 'participation constraint'. Given that we rule out time-consistency problems, the argument of the contribution function $L$ can be taken equivalently as the platform announced by candidate $i$ before the election or as the decision actually made by $i$ once (if) in power. What matters is that $L\left(x_{t}^{i}\right)$ is paid out only if $i$ is in power. ${ }^{9}$ The value of being in office is thus now the sum of the rent $\rho$ plus access to lobby contributions $L_{t}^{i}=L\left(x_{t}^{i}\right)$, and politician $i^{\prime}$ s problem is

$$
\max _{\left\{x_{t}^{i}\right\}} \sum_{t=0}^{\infty} \beta^{t} \phi_{t}^{i}\left(\rho+L_{t}^{i}\right)=\sum_{t=0}^{\infty} \beta^{t}\left[\frac{1}{2}+\iota+b\left(v_{t}^{i}-v_{t}^{j}\right)\right]\left(\rho+L_{t}^{i}\right) .
$$

The Euler equation is

$$
b \frac{\partial v_{t}^{i}}{\partial x_{t+1}^{i}}\left(\rho+L_{t}^{i}\right)+\beta\left[b \frac{\partial v_{t+1}^{i}}{\partial x_{t+1}^{i}}\left(\rho+L_{t+1}^{i}\right)+\phi_{t+1}^{i} L^{\prime}\left(x_{t+1}^{i}\right)\right]=0,
$$

or, substituting for $\partial v_{t}^{i} / \partial x_{t+1}^{i}, \partial v_{t+1}^{i} / \partial x_{t+1}^{i}$, and $L^{\prime}\left(x_{t+1}^{i}\right)$,

$$
\begin{aligned}
\mu b\left(\rho+L_{t}^{i}\right) z_{t}^{i} & =\beta b\left[f_{x}^{0}+u^{\prime} f_{x}^{1}-2 \widetilde{\omega}_{t+1}+(1-\delta) \mu z_{t+1}^{i}\right]\left(\rho+L_{t+1}^{i}\right) \\
& +2 \beta \phi_{t+1}^{i} \widetilde{\omega}_{t+1} .
\end{aligned}
$$

The system's dynamic properties are again unchanged, and steady-state infrastructure investments $z^{i}$ are defined implicitly by

$$
z^{i}=\frac{\widetilde{\beta}}{\mu}\left(f_{x}^{0}+u^{\prime} f_{x}^{1}-2 \widetilde{\omega}\right)+\frac{2 \widetilde{\beta} \phi^{i} \widetilde{\omega}}{\mu b\left(\rho+L^{i}\right)} .
$$

Given (19), the lobby sets the function $L\left(x_{t}^{i}\right)$ so as to leave him, ex ante, just indifferent between accepting and rejecting the bribing deal. Comparing (19) with the electoral

\footnotetext{
${ }^{9}$ The lobby can be seen as a principal and the government of an agent, but with only one lobby, we do not need to treat the game formally as a dynamic common-agency game (on this, see Bergemann and Valimaki, 1998).
} 
equilibrium (16), it can be seen that the distortions generated by lobbying are all subsumed in an additive term $\gamma^{i}=2 \widetilde{\beta} \phi^{i} \widetilde{\omega} / \mu b\left(\rho+L^{i}\right)$ whose properties can be readily interpreted. ${ }^{10}$

First, observe that as $\widetilde{\omega}$ grows, so does $\gamma^{i}$ : a higher level of the public utility's rent makes it more aggressive in demanding additional infrastructure investment at the taxpayer's expense. Suppose that $\widetilde{\omega}$ is a regulated rate. If one thinks of a high $\widetilde{\omega}$ as being a "policy mistake", its cost is not just the deadweight losses generated by wrong pricing, but also the encouragement given to lobbying on other policy dimensions (here the level of infrastructure investments). If, on the other hand, one thinks of a high $\widetilde{\omega}$ as being the result of past rent-seeking activities, those activities display a kind of increasing returns. This result applies potentially to all infrastructure-dependent regulated utilities. However, note that, compared to the social optimum (12), the effects of excess pricing of the infrastructure on electoral concerns and on lobbying work at cross-purposes, as excess pricing leads to underprovision through electoral concerns but overprovision through lobbying. Thus, trying to curb only one of the distortions may actually make things worse. This is a straightforward application of the second-best principle according to which reducing one distortion in the presence of another one does not necessarily take society closer to the social optimum. Here, the appropriate policy to deal with all distortions at once would be simply to get the infrastructure's access price right.

Second, as $\rho$ goes up, $\gamma^{i}$ goes down; that is, an increase in the fixed component of the rent from being in office produces a 'better' infrastructure policy (again, 'better' is relative to the electoral equilibrium; not necessarily relative to the social optimum). The reason is that as pure electoral concerns by themselves do not generate departures from the social optimum, as $\rho$ grows, distortions tend to be reduced. Put simply, the higher the value of being in office, the more politicians try to placate voters to get there.

Third, a decrease in $\iota$, the exogenous component in $\phi^{i}$, reduces $\gamma^{i}$. The reason is that, with a lower election probability, the expected gain from placating the lobby by promising the policy it wants is more heavily discounted by the probability of not being elected. Ceteris paribus, this reduces the power of the lobby's incentive scheme $L($.$) . According$ to this logic, and absent any partisan preferences, a small party with only small chances

\footnotetext{
${ }^{10}$ Note that because election probabilities depend on $\iota$, politicians $i$ and $j$ no longer face the same problem and hence choose different platforms. However, evaluating (19) at $\iota=0$, platforms become identical again and equilibrium election probabilities are $1 / 2$ for each. In this case comparative dynamics on $\iota$ is done around zero.
} 
of being elected, or a challenger facing an uphill battle against an exogenously popular incumbent, can be expected to offer platforms that are less polluted by special-interest influence. Of course, things would be different if special interests contributed before the election, instead of after it, and if their contributions were invested in the campaign and substantial enough to affect the election's expected outcome: placating the lobby would then be a way of raising the probability of being elected. The dynamics of a campaign-contribution model would clearly need to be specified differently from that of a corruption model such as ours.

Finally, observe that an increase in $b$ reduces $\gamma^{i}$. The reason is as follows: recall that $b$ is an inverse measure of the spread of the distribution of the voting shock $\varepsilon$ (a distribution parameterized by $b$ dominates one parameterized by $b^{\prime}$ in the second order whenever $b^{\prime}<b$ ). As $b$ grows, a given departure from (16) designed to placate the infrastructure lobby becomes more expensive in terms of expected vote loss, because a larger mass of voters 'swing' for a given utility differential.

That swing voters discipline politicians by raising the power of electoral incentives is not surprising; what is more so is that this involves a lower infrastructure stock (and lower investments), as is the case in (19) where the distortion term $\gamma^{i}$ is positive. This, however, depends on who is affected by the cost of infrastructure investments. Suppose first that this cost, instead of being borne by the electorate at large as we assumed so far, was borne by 'a lobby', by which we mean a small set of individuals who (by virtue of their feeble electoral weight) have an interest in organizing themselves. Instead of lobbying leading to too much investment from the electorate's standpoint, it would lead to too little, and then swing voters would get more. As far as transportation infrastructure is concerned, however, the most active lobbies are likely to be pro-spending lobbies, and this is consistent with the formulation adopted here.

Second, suppose that the cost of infrastructures, instead of being borne locally, was pooled across several political entities (regions or states). This would give rise to a common-pool problem whereby local electorates and lobbies both want more spending since they can shift part of the fiscal burden onto others. This issue, which we formally integrate in the model in the following section, is important in a regional infrastructure allocation problem. 


\subsubsection{Infrastructure allocation across regions}

The crucial importance of infrastructure access pricing in shaping the forces of lobbying is, in general, a plausible feature of the model used in previous sections. However, as far as transportation infrastructure is concerned, pricing is unlikely to be a key issue; moreover, even in countries such as France where highway operators are semi-private, ${ }^{11}$ they are unlikely to be a powerful lobby. Instead, our empirical exploration below will build on a version of the model developed in this section where lobbying is done by infrastructure users, yielding a formulation where infrastructure investments are distorted even when the pricing is right. We also add a cross-regional allocation problem. Let $A$ and $B$ denote two regions of equal size. Politician $i$, who can be thought of as a multi-region party, maximizes the sum of expected office rents (appropriated by its members if $i$ is a party rather than an individual) in both regions, by solving

$$
\max _{\left\{x_{t}^{i A}, x_{t}^{i B}\right\}} \sum_{t=0}^{\infty} \beta^{t} \sum_{k=A, B} \phi_{t}^{i k}\left(\rho+L_{t}^{i k}\right)=\sum_{t=0}^{\infty} \beta^{t} \sum_{k=A, B}\left[\frac{1}{2}+\iota^{k}+b^{k}\left(v_{t}^{i k}-v_{t}^{j k}\right)\right]\left(\rho+L_{t}^{i k}\right) .
$$

subject to the laws of motions of the two regional infrastructure stocks:

$$
x_{t+1}^{k}=(1-\delta) x_{t}^{k}+z_{t}^{k}, \quad k=A, B .
$$

Suppose that, in each region, sector zero is the narrow-based lobby, whereas shareholding in sectors one and two is widely spread in the electorate. Suppose also that regions $A$ and $B$ split the fiscal burden of infrastructure investments equally, irrespective of the allocation of spending between them. Voter income is now

$$
I_{t}^{k}=\pi_{t}^{1 k}+\pi_{t}^{2 k}-\mu\left(z_{t}^{A}+z_{t}^{B}\right)^{2} / 2=p_{t}^{k} f^{1}\left(x_{t}^{k}, 1-\ell_{t}^{k}\right)+\widetilde{\omega}_{t}^{k} x_{t}^{k}-\mu\left(z_{t}^{A}+z_{t}^{B}\right)^{2} / 4,
$$

and, letting $z_{t}=\left(z_{t}^{A}+z_{t}^{B}\right)$, the corresponding indirect utility function is

$$
v_{t}^{i k}=p_{t}^{k} f^{1}\left(x_{t}^{k}, 1-\ell_{t}^{k}\right)+\widetilde{\omega}_{t}^{k} x_{t}^{k}-\mu z_{t}^{2} / 2+u\left(c_{t}^{1 k}\right)-p_{t}^{k} c_{t}^{1 k}
$$

Let $\bar{b}=b^{A}\left(\rho+L_{t}^{i A}\right)+b^{B}\left(\rho+L_{t}^{i B}\right)$. The Euler equations satisfy

$$
\mu \bar{b} z_{t}^{i} / 2=\beta\left[b^{k} u^{\prime} f_{x}^{1}\left(x_{t+1}^{i k}\right)\left(\rho+L_{t+1}^{i k}\right)+(1-\delta) \bar{b} \mu z_{t+1}^{i} / 2+\phi_{t+1}^{i k} L^{\prime}\left(x_{t+1}^{i k}\right)\right], \quad k=A, B,
$$

\footnotetext{
${ }^{11}$ Most of France's autoroute (motorway) network is built out of public funds but operated under license by mixed-ownership companies.
} 
and, as local contributions satisfy $L^{\prime}\left(x_{t}^{i k}\right)=d \pi_{t}^{0 k} / d x_{t}^{i k}=f_{x}^{0}\left(x_{t}^{k}, \ell_{t}^{k}\right)-\widetilde{\omega}_{t}^{k}$, the steady-state infrastructure investment $z^{i k}$ proposed by politician $i$ for region $k$ satisfies

$$
\frac{z^{i A}+z^{i B}}{2}=\frac{\widetilde{\beta} b^{k}\left(\rho+L^{i k}\right)}{\mu \bar{b}}\left(u^{\prime} f_{x}^{1 k}+\widetilde{\omega}^{k}\right)+\frac{\widetilde{\beta} \phi^{i k}}{\mu \bar{b}}\left(f_{x}^{0 k}-\widetilde{\omega}^{k}\right), \quad k=A, B .
$$

If infrastructure access is priced at the socially optimal level $\left(\widetilde{\omega}^{k}=0, k=A, B\right)$, after substitution of the equilibrium value of $L^{i k}$ this becomes

$$
\frac{z^{i A}+z^{i B}}{2}=\frac{\widetilde{\beta} \rho b^{k}}{\mu \bar{b}} u^{\prime} f_{x}^{1}\left(x^{k}\right)+\frac{\widetilde{\beta} \phi^{i k}}{\mu \bar{b}} f_{x}^{0}\left(x^{k}\right), \quad k=A, B .
$$

Direct comparisons of (22) with the social optimum (11) are ambiguous. However, (22) has positive implications for the level of the steady-state infrastructure investments that can be indirectly tested against the data. (The test is only indirect since actual observations are not necessarily measured at the steady state -more on this below.)

First, as $\widetilde{\beta}(\iota+1 / 2) / \mu \bar{b}>0$ and the term $f_{x}^{0}\left(x^{k}\right)$ picks up the effect of lobbying, it is clear that if sector zero ("the lobby") is unorganized or nonexistent, the infrastructure level is lower; so if, of two regions, one has a larger lobby, ceteris paribus, it will also have more infrastructure. Perhaps more importantly, tedious but straightforward calculations show that if, starting from a position where $b^{A}=b^{B}, b^{A}$ increases while $b^{B}$ decreases proportionately so as to leave $\bar{b}$ constant, $x^{A}$ and consequently $z^{A}$ go up. Thus, regions with either strong lobbies (large $L^{k \prime}$ ) or 'swing' electorates (large $b^{k}$ ), or both, benefit from more infrastructure spending in the steady state, a reflection of the common-pool problem.

It is worth noting that in a case of 'political symmetry' defined by $b^{A}=b^{B}(=b)$ and $\iota^{A}=\iota^{B}(=\iota), \bar{b}=2 \rho b$, and $(22)$ reduces to

$$
z^{i A}+z^{i B}=\frac{\widetilde{\beta}}{2 \mu} u^{\prime} f_{x}^{1}\left(x^{k}\right)+\frac{\widetilde{\beta}}{2 \mu \rho b}(\iota+1 / 2) f_{x}^{0}\left(x^{k}\right), \quad k=A, B .
$$

Clearly, if the second term, which picks up the effect of influence activities, is nonexistent, variations in infrastructure investments across regions can come only from variations in the marginal product of infrastructure $f_{x}^{1}$. Consider a Cobb-Douglas case $y^{1 k}=f^{1}\left(x^{k}, \ell^{k}\right)=\left(x^{k}\right)^{\alpha_{x}}\left(\ell^{k}\right)^{\alpha_{k}}$ : then $f_{x}^{1}=\alpha_{x} y^{1 k} / x^{k}$. If the ratio $y^{1 k} / x^{k}$ does not vary too much across regions, eliminating influence activities leads to a uniform allocation rule. 
The model outlined so far is suggestive of a number of variables that can be considered as likely drivers of infrastructure investment decisions across regions. In the following section, we will take these hypotheses to the data and show that they do indeed find support.

\section{Empirical estimation}

In this section, we estimate simultaneously a system of two equations. The first is a production function $q=f(k, \ell, x)$ of the Cobb-Douglas form:

$$
\ln q_{i t}=\alpha_{0 t}+\alpha_{\ell} \ln \ell_{i t}+\alpha_{k} \ln k_{i t}+\alpha_{x} \ln x_{i t}
$$

where, using subscripts $i$ for regions and $t$ for time, aggregate value added at the regional level $\left(q_{i t}\right)$ is regressed in log form on fixed time-effects $\left(\alpha_{0 t}, t=1 \ldots T\right)$, employment $\left(\ell_{i t}\right)$ and the stocks of capital $\left(k_{i t}\right)$ and transportation infrastructure equipment $\left(x_{i t}\right) .{ }^{12}$ Using tildas to denote variables per worker, so $\widetilde{q}_{i t}=q_{i t} / \ell_{i t}$, and so on, (23) can be rewritten as

$$
\ln \widetilde{q}_{i t}=\alpha_{0 t}+\widetilde{\alpha}_{\ell} \ln \ell_{i t}+\alpha_{k} \ln \widetilde{k}_{i t}+\alpha_{x} \ln \widetilde{x}_{i t}
$$

where $\widetilde{\alpha}_{\ell}=\alpha_{k}+\alpha_{x}+\alpha_{\ell}-1$. Constant returns to scale are rejected if $\widetilde{\alpha}_{\ell}$ is estimated to be significantly different from zero. The second equation is a "policy function"

$$
z_{i t} / \ell_{i t}=\theta_{0 t}+\theta_{1} \psi\left[f_{x}\left(x_{i t}\right)\right]+\theta_{2} L_{i t}+\theta_{3} e_{i t}
$$

where regional infrastructure investments per worker $z_{i t} / \ell_{i t}$ (the normalization is to account for heterogeneous region sizes) are regressed on time effects $\left(\theta_{0 t}\right)$, an increasing function $(\psi)$ of the marginal product of the regional infrastructure stock $\left(f_{x}\left(x_{i t}\right)\right.$, a measure of the economic return to infrastructure investments), a measure of lobbying capacity ( $L_{i t}$, the number of large firms), and a vector $e_{i t}$ of proxies for electoral concerns. The results reported below are based on a linear form for $\psi$; a log form was tried with similar results. We also estimated (24) with $L_{i t}$ replaced by $L_{i t} / \ell_{i t}$, the number of large firms per worker, with similar although slightly less significant results.

\footnotetext{
${ }^{12}$ Taking seriously the steady-state assumption of the previous section, our growth equation should also be based on the steady-state equation of a growth model; however, neither savings rates nor rates of technical change are likely to vary much across regions.
} 


\subsection{Data and Summary Statistics}

We use a panel data set covering 21 of France's 22 regions (we excluded Corsica because of its poor data) over 1985-92. Table 1 provides a brief description of the variables and a list of the relevant regions. All figures are in 1992 Francs. Output $q$ (henceforth $V A L)$ is measured as value added at factor cost and has been obtained from the Eurostat database 'New Cronos' (June 1999). Regional employment $\ell(E M P)$ is also taken from 'New Cronos' and covers all private sectors of the economy. The private capital stock $k(C A P)$ is constructed by the Laboratoire d'Observation Economique et des Institutions Locales (OEIL) using national data from INSEE's Compte de Patrimoine and allocating the national stock to the regions on the basis of corporate tax rates.

The transportation infrastructure stock $x$ (INFRAST) is constructed as follows. As stock data was not available at the regional level, we construct the stock from investment data using the perpetual inventory method (PIM). In order to obtain a benchmark stock level for the initial period, we allocate the national stock, for which data is given by the Fédération Nationale des Travaux Publics (FNTP, see also Laguarrigue, 1994) across the 21 regions in proportion to their average investment share over the first three years of the sample period. The relatively slow rate of depreciation of infrastructure capital implies that our stock converges slowly to the true one. In order to reduce possible biases in the calculation of the infrastructure stock we use infrastructure investment data going back to 1975. Aggregating our regional stock data to the national level and comparing it with national data obtained from INSEE yields only marginal differences.

The transportation infrastructure investment data (INV) come from several sources. Railway figures were provided directly by SNCF, the national railway company. Highway figures, which are reported for the year in which the work is done (rather than for the year of budget allocation - there is a delay between the two) have been collected by the OEIL from data generated by the FNTP (see Fritsch and Prud'homme, 1994, for details). The FNTP's data are based on reports by the Federation's member companies. Finally, investment data for waterways was taken directly from the FNTP's statistical yearbook. Although airport construction data, which we had collected from the Direction Générale de l'Aviation Civile (DGAC), would have been a natural inclusion in the study, we found that they were not sufficiently reliable and consequently eliminated them from this study.

The number of industrial establishments with more than 500 employees (LARGE), 
our proxy for lobbying forces, is taken from various issues of L'Industrie dans les Régions, a yearly statistical publication of the Ministry of Industry.

As for our electoral-concern proxies, the first is DIFF, the difference in absolute value between the electoral scores of the left-wing and right-wing coalitions in the 1986 and 1992 regional elections. ${ }^{13}$ DIFF is not a proxy for the proportion of swing voters, since it is the outcome of the vote rather than a characteristic of voters. However, inasmuch as it is correctly anticipated, a close race can be taken, somewhat loosely, as conducive to pork-barrel, because it raises the probability of affecting the outcome with any given amount of spending and consequently raises the marginal profitability of spending. Thus, the parameter estimate on DIFF should intuitively be expected to have a negative sign in the policy equation. The second proxy, $L E P E N$, is the combined score of the Front National and Chasse, Pêche, Nature et Tradition. This is, according to our reasoning about the nature of the Front National constituency, a more direct measure of the proportion of at least one type of swing voters. In the presence of a common-pool problem, swing voters want more spending: the LEPEN coefficient estimate should therefore have a positive sign. Finally, INCUMB is the incumbent's margin, which is one possible measure of the parameter $l$ : as a higher exogenous probability of winning reinforces the power of the lobby's incentive, a higher value of INCUMB should induce more spending, and its parameter estimate should accordingly be positive. Moreover, as $\phi^{i k}$ and $L^{i k \prime}$ enter multiplicatively in (21), we expect a positive and significant parameter estimate on the interaction term INCUMB * LARGE.

For off-election years, we have tried three different formulations for DIFF and LEPEN: a backward-looking one using the previous election's score, a forward-looking using the next election's score, and a mixture with moving weights, reflecting increasing accuracy and influence of opinion polls as elections approach. All three yielded qualitatively similar results, with slightly better ones for the third approach (mixture), which is the one we report in Table 3. For $\operatorname{INCUMB}$, only the forward-looking formulation makes sense. Finally, the dummy variable PARTY is equal to one when the majority

\footnotetext{
13“Right wing" was defined in the sample as RPR, UDF and "Divers Droite". Given that mainstream right-wing parties refused to form alliances with the far-right Front National, the latter was excluded from the definition of the right wing. "Left wing" was defined as Parti Socialiste, Parti Communiste, Mouvement des Radicaux de Gauche, and Generation Ecologie, a pro-government environmentalist party, but excluded "Les Verts", a more radical one which formed an alliance with the Socialists only later on, and "Divers Gauche". The "Divers Gauche" and "Divers Droite" categories classify independent individuals according to their voting patterns. For instance, France Unie is classified as "Divers Droite" before it rallied the Presidential majority in 1988, and "Divers Gauche" thereafter.
} 
in a Regional Council (and hence the affiliation of the region's President) and that of the government are either both right-wing or both left-wing, and zero otherwise. Thus, PARTY picks up specifically that part of spending that is decided upon in Paris and that is targeted at local political allies. As our sample includes two regional elections (in 1986 and 1992) and two national legislative elections (in 1986 and 1988), PARTY, which was constructed using press sources, varies both across regions and across time. We have lagged all electoral variables by one year to take account of budget delays.

\section{TABLE 1 HERE}

Table 2 shows descriptive statistics for these variables. In 1992 Francs, over the sample period, average infrastructure investment amounted to 1396 Francs per worker, or roughly 0.54 percent of GDP; the infrastructure stock amounted to 50,920 Francs per worker, or 19.8 percent of GDP. The value of the highway infrastructure stock was about 5 times that of the railway stock and 70 times that of the waterways infrastructure stock.

TABLE 2 HERE

\subsection{Estimates}

Slightly rewriting (23) and (24), the system to be estimated is thus:

$$
\begin{aligned}
\ln V A_{i t} / E M P_{i t} & =\alpha_{t}+\alpha_{k} \ln \left(C A P_{i t} / E M P_{i t}\right)+\alpha_{\ell} \ln E M P_{i t} \\
& +\alpha_{x} \ln \left\{\left[\left(1-\delta_{t}\right) * I N F R A S T_{i t-1}+I N V_{i t}\right] / E M P_{i t}\right\}+\alpha_{p} P A R I S+v_{1 i t} \\
I N V_{i t} / E M P_{i t} & =\theta_{t}+\theta_{1} \alpha_{x} V A_{i t} / \text { INFRAST }_{i t-1}+\theta_{2} \text { LARGE }_{i t-1} \\
& +\theta_{3} \text { DIFF }_{i, t-1}+\theta_{4} \text { LEPEN }_{i, t-1}+\theta_{5} \text { PARTY }_{i, t-1}+v_{2 i t}
\end{aligned}
$$

where $v_{k i t}=\rho_{k} v_{k i, t-1}+\varepsilon_{k i t}, k=1,2$, and $\varepsilon_{k i t}$ are i.i.d. normal variables with mean zero and variance $\sigma_{k}$. We do not impose constant returns to scale in the production function. As for the infrastructure stock variable, we have decomposed it into the sum of a lagged, depreciated value of the stock $\left(\left(1-\delta_{t}\right) * I N F R A S T_{i t-1}\right)$ plus gross investment measured at end of period. Thus, using the notation of Section 2, the dynamics of the infrastructure stock is

$$
x_{i t}=(1-\delta) x_{i t-1}+z_{i t}
$$


rather than (7). The endogenous variable is $I N V_{i t}$. In the policy function, the term $\theta_{1}\left(\alpha_{x} V A_{i t} /\right.$ INFRAST $\left.T_{i t-1}\right)$ picks up the effect of the marginal product of the infrastructure stock (with a Cobb-Douglas production function, this is $\alpha_{x} q / x$ ).

The estimation procedure is as follows. We estimate (25) and (26) simultaneously by non-linear Full-Information Maximum Likelihood (FIML), ${ }^{14}$ using a Prais-Winston transformation which avoids omitting observations for $t=1$, (Greene 1997, p. 601). We obtain the autocorrelation parameters $\rho_{k}, k=1,2$, in a first step by consistent estimates. The results are reported in Table 3.

Endogeneity of the number of large establishments is a potential source of problem. Indeed, regional private capital stocks could be expected to be affected by regional levels of transportation infrastructure if firm location is endogenous (on this, see Aschauer 1989b; see also Combes and Lafourcade (2001) for a recent attempt to estimate the effects of transportation cost declines on the location of economic activity in France). However, we performed a Hausman test and found that endogeneity of the private capital stock and employment were both rejected at the 5\% level. The reason may be that the private capital stock includes a substantial fraction of small and medium-sized local companies whose inter-regional mobility is limited. It may also be that net investments are too small relative to stocks of existing capital for feedback effects to be felt significantly in the stocks over our relatively short sample period. Having treated explicitly the endogeneity bias on the infrastructure stock and having found it to be nonexistent (more on this below), given also the test's results, we feel reasonably confident that any endogeneity bias on the private capital stock would be small enough to leave our empirical results largely unaffected. We therefore leave for further research the treatment of location-related issues, which might be better dealt with using a panel of longer duration than ours. By contrast, the endogeneity problem cannot be brushed aside so easily for large firms, which are likely to be more mobile than small ones. Short of specifying a full location equation, we have instrumented the number of large establishments with its lagged value (without much change in the results, lending further support to our argumentation above). Similar endogeneity issues arise for election results, which might arguably be sensitive to infrastructure allocation decisions. Of the two regional elections in our sample period (1986 and 1992), only the 1992 is a potential problem, since the 1986 is one year after the beginning of our sample and can accordingly be taken as

\footnotetext{
${ }^{14}$ Estimations have been carried out using PROC MODEL, SAS 8.02.
} 
largely predetermined. Instrumenting 1992 election results with 1986 ones gave disappointing results as 1986 results are a rather poor instrument for 1992 ones. Given that the loss of information appeared to be serious whereas, elections being typically played on broader issues than just kilometers of roads, the endogeneity bias's importance was unclear, we decided to keep 1992 results on the right-hand side.

Several specification tests were performed. In order to test the $\mathrm{AR}(1)$ specification against the alternative of an $\operatorname{AR}(2)$ specification, we employed the Godfrey Lagrange multiplier test for non-linear regression models (Godfrey 1988, p. 117; White 1992). This test statistic has a critical value of 6.635, which implies acceptance of the AR(1) process at a 1 percent level for all our specifications (see Table 3). We also performed White's test for heteroscedasticity, which is because of its generality also an indicator for functional form misspecification. This statistic is distributed $\chi^{2}$ with 45 degrees of freedom for the production function and 93 degrees of freedom for the policy equation. Thus, homoscedasticity of errors and functional form specification is not rejected at a $1 \%$ level both for the production function and the policy equation. It is also comforting that normality of the error structure is not rejected at a $1 \%$ level applying a system test (Henze-Zirkler T). The estimated $\operatorname{AR}(1)$ parameters $\rho_{1}$ and $\rho_{2}$ are about 0.88 and 0.48 respectively.

\section{TABLE 3 HERE}

Two preliminary remarks on Table 3's results are in point. First, the proportion of the variability in regional infrastructure investments explained by the policy equation is high (the $R^{2}$ is 0.87 ), given that the equation includes only DIFF, PARTY and two regional dummies as out-of-model explanatory variables. Second, the reported parameter estimates turn out to be fairly robust across estimation procedures (OLS and FIML) as well as with respect to changes in the lobbying variable.

All parameter estimates for electoral variables have the expected signs, and all except PARTY are significant at the 1\% level, providing strong evidence of pork-barrel and supporting the hypothesis that public goods, even if imperfectly "targetable" (we use here the term coined by Lizzeri and Persico), are used by politicians as redistribution instruments. The parameter estimate on LARGE is also significant at the $1 \%$ level, and the positive and highly significant parameter estimate on the interaction term $I N C U M B * L A R G E$ provides empirical support for the functional form in (21) since it 
suggests that, just as predicted, incentives to placate lobbies are stronger for politicians

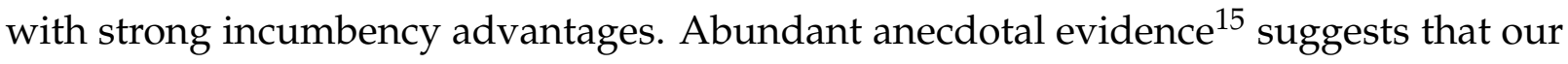
results capture a phenomenon that is widely perceived as important. A caveat is in point, however. In our last formulation, lobbying comes from users of transportation infrastructure, whereas in reality, the construction industry itself is an active lobbyist as far as new motorway and high-speed train construction projects are concerned. Although the construction industry as a whole has a fairly low concentration, the lobbies behind large projects include a few large firms for whom location of the work is irrelevant. By contrast, many of the firms that care about where the work is done are small ones, and some are necessarily below our cutoff of 500 employees (a construction lobbyist once boasted that the industry association has " 52,000 members, practically one in each commune"). ${ }^{16}$ By contrast, time dummies do not suggest a discernable election-year pattern.

If the positive results concerning lobbying and electoral concerns were to be expected-although perhaps not as clear-cut as they turned out to be-the insignificance of the productivity term, which picks up the government's concern to allocate infrastructure investments to where their marginal product is highest, is more puzzling. Although it is certainly possible that the government simply doesn't care about the efficient allocation of resources, this conclusion is probably a strong one to draw from such limited evidence and given the scope for misspecification in a simple political-economy model. Moreover, the variety of state-aid schemes aimed at fostering stronger growth in backward regions suggests that European governments, including the French one, do care about convergence-unless, of course, these state-aid schemes are themselves driven by lobbying forces. It is therefore fair to say that, as far as this study is concerned, government objectives in the allocation of transportation infrastructure investment are unclear once political motivations are controlled for. (We tried including regional unemployment rates as a right-hand side variable in the policy equation, but it proved insignificant.)

Quantitative estimates are, of course, sensitive to model specification (although estimates proved remarkably stable) but they nevertheless provide a rough estimate of

\footnotetext{
${ }^{15}$ See for instance the cover story of the magazine Capital (June 18, 1998) entitled "100 lobbies qui font la loi en France"; in particular pp 92-ff. According to the magazine, the construction industry is a major political-campaign contributor and a powerful force behind highway construction projects, although lobbying by French firms is expected to decline as a result of a Brussels directive imposing open bidding procedures (and therefore diluting the return to lobbying).

${ }^{16}$ Capital, 18 June 1998, p. 92.
} 
the orders of magnitude involved, and it is instructive to take a look at them, albeit a very cautious one. Ceteris paribus, an additional "representative" large establishment in a region brings that region 8.63 French Francs (FF) of additional infrastructure investment per worker each year; or, with an average of 1, 022,000 workers, a total of 8.819 million FF (the number of large establishments per region varies between 5 in Limousin and 113 in Rhône-Alpes). A one-standard deviation (6.2 percentage points) increase in the Front National and hunters' vote brings a region between 134.54 FF and 160.58 FF of additional infrastructure investment per worker, or 137.5 to 164.11 million FF for the average region (9.6\% to $11.5 \%$ of average spending).

Production-function estimates are significant and have the expected sign. Constant returns to scale are not rejected, although the test statistic is borderline. The estimated elasticity $\widehat{\alpha}_{k}$ of private capital is 0.18 and is significant at the $1 \%$ level; that of infrastructure $\widehat{\alpha}_{x}$ is 0.08 and significant at the 5\% level. All estimates are remarkably stable across estimation procedures. In particular, the OLS infrastructure elasticity estimate is very close, suggesting, as noted in the introduction, that the simultaneous-equation bias from OLS estimation of the production function is negligible. Our estimate of the infrastructure share is much lower than Aschauer's (1989) estimate on US aggregate data (0.39) but the two are not directly comparable since Aschauer's infrastructure variable was a broad aggregate of public capital whereas ours is limited to transportation infrastructure. Munnell's (1990) estimate, which was more directly comparable to ours in that she used state-level data, was 0.14, whereas de la Fuente and Vives' (1995) estimate on Spanish regional data was somewhat higher than ours. Although plausible, our estimate should nevertheless be interpreted cautiously, as $\widehat{\alpha}_{x}$, in all likelihood, picks up not only the supply-side effects of infrastructure investments (what it is meant to measure) but also their demand-side or Keynesian effects; it is in fact possible that the latter dominates the former. Moreover, as we noted earlier, a common drawback of the productionfunction approach is that it takes the private capital stock as fixed, which can be a valid approximation of reality only in the short run (see de la Fuente and Vives, 1995, for a discussion and alternative formulation); the same is true of employment.Thus, our estimates are best construed as short-term ones. Finally, we have not included human capital for lack of reliable data; although this is, in general, a potentially serious omission, systematic cross-regional variation in educational levels also may not be a serious a problem given France's relatively egalitarian education system. 
As the rates of return on infrastructure capital implied by production-function estimates have been a subject of intense debate in the US (see e.g. CBO, 1988, or Gramlich, 1990), it is instructive to calculate the rates of return implied by our estimates for private and infrastructure capital. Let $r_{k}$ be the rate of return on private capital; in a competitive environment the unconstrained demand for private capital is given by $r_{k}=\widehat{\alpha}_{k} q / k$. Assuming that the stock of private capital is at its long-run equilibrium level and using national aggregates of $q$ and $k$ averaged over our sample period, the implied rate of return is 0.157 , which is lower than estimates from US data (see e.g. Munnell, 1990b) but nevertheless plausible. As for infrastructure, the implied rate of return, using again national aggregates averaged time-wise, is $r_{x}=\widehat{\alpha}_{x} q / x=0.44$; this is higher than the upper bound of the range of values reported by the US Congressional Budget Office, which vary between 0.35 for highway maintenance projects and 0.05 for new rural highway projects (see Gramlich, 1994, table 4). Thus, the high rate of return on infrastructure capital implied by our elasticity estimate suggests that in France's case there is some ground to the claim that, overall, transportation infrastructure is underprovided; in fact, using our elasticity estimates, the value of the infrastructure stock that would bring its rate of return down to the rate of return on private capital would be 140,625 Francs per worker (roughly $\$ 19,000$ at the current exchange rate), or three times the current one. However, the difference in rates of return between private and infrastructure capital should not be overplayed, as rates of return are very sensitive to elasticity estimates, which are themselves fairly imprecise. ${ }^{17}$ Moreover, France was, during our sample period, in the middle of a major effort of transportation infrastructure construction, both for highways and for high-speed railway lines. The picture might be different a decade later.

\section{Concluding Remarks}

The primary interest of our results is that they highlight the importance of the porkbarrel dimension of policy-making. They suggest that modelling explicitly the political processes that drive policy decisions is interesting in its own right, irrespective of whether their omission would or would not introduce a simultaneity bias in regressions where policy variables are treated as exogenous. Commenting on the high rates of re-

\footnotetext{
${ }^{17}$ In fact, the difference between $r_{x}$ and $r_{k}$ is statistically not significant at a 10 percent level.
} 
turn on infrastructure investments estimated by Aschauer, Gramlich (1994) remarked, "If public investment really were as profitable as claimed, would not private investors be clamoring to have the public sector impose taxes or float bonds to build roads, highways, and sewers to generate these high net benefits? [...] Very little such pressure seems to have been observed, even when the implied econometric rates of return were allegedly very high" (p.1187). We find that, in the absence of a loud clamor, the quiet whisper of lobbies can indeed be heard; but not necessarily because of high rates of return. We also find, and that is perhaps more important, that roads and railways are not built to reduce traffic jams: they are built essentially to get politicians reelected.

As far as policy implications are concerned, our results contain good news and bad news. The bad news is that pork-barrel matters, whereas other governmental objectives, if any, are unclear. The good news is that the resulting distortions appear to be relatively small. First, feedback effects on production-function estimates are weak, and the marginal product of infrastructure capital does not vary tremendously across regions, so that departures from the first-best allocation of infrastructure across regions are fairly inconsequential. Second, in rich industrial countries, transportation infrastructure investments are small compared to the level of existing stocks, so that political distortions in the amounts and spatial allocation of investments are unlikely to make themselves felt on GDP before a while. But one should not be excessively optimistic about this. First, if investment decision have always been made on the basis of pork-barrel politics, the stock levels should themselves be severely distorted. So our results beg the question: when did things start getting seriously bad? In France's case, the answer seems to be, fairly recently. The conventional wisdom among political scientists is that corruption has vastly expanded in the 1980s, largely as a result of administrative reforms enacted in 1982. ${ }^{18}$ Second, if pork barrel is prevalent in infrastructure-investment decisions (although de la Fuente and Vives (1995) found little trace of political influence in Spanish infrastructure investment decisions), developing countries are likely to be less robust to the ensuing distortions simply because the stocks are so much smaller relative to the investments. Under such conditions, political distortions in the allocation mechanisms are unlikely to be innocuous.

If, as our positive analysis suggests, political distortions ought to be taken seriously,

\footnotetext{
${ }^{18}$ See e.g. Mény, 1992; Borraz and Worms, 1996; or SCPC, 1994. We are grateful to Jean-Louis Briquet, from the Institut $d^{\prime}$ Etudes Politiques de Paris, for a useful conversation on this and for attracting our attention to the relevant political-science work.
} 
at least in the long run, one should be able to offer normative guidance for the design of rules or institutions that could mitigate those distortions. The second interesting aspect of our results is that they provide just such a rule. We showed in Section 2 that the lobbying-free allocation of infrastructure is uniform if its marginal product $\left(\alpha_{x} q_{i t} / x_{i t}\right.$ under a Cobb-Douglas technology) does not vary across regions. Provided that neither productivity levels nor infrastructure stocks per worker vary too much across regions (our data suggests that they don't: the standard deviation of infrastructure's marginal product is 0.067 , for a mean of 0.44 , a minimum of 0.32 in Provence and a maximum of 0.56 in Alsace), uniform allocation is thus a fairly good rule of thumb. Even if the ratio $\alpha_{x} q_{i t} / x_{i t}$ varies, it is not a very difficult one to compute, so the more sophisticated rule is itself not excessively demanding. Of course, if the rule is clear, how it should be implemented is less so. Delegation to an independent policy-making body may be one answer, whether this body is an independent national agency, like a regulator or a central bank, or an unelected supranational body like the EU Commission. Another answer lies at the opposite extreme of the spectrum: rather than sheltering policymakers, it consists of exposing them. Recent work by Besley and Burgess (2001) on India highlights the power of the press in disciplining politicians. What mixture of sheltering and exposure would best control pork-barrel politics is a question that we leave open; only careful international comparisons will shed light on it. What is clear from our work is that France does not yet seem to have the answer.

\section{References}

[1] Aschauer, David A. (1989a), "Is Public Expenditure Productive?", Journal of Monetary Economics 23, 177-200.

[2] - (1989b) "Does Public Capital Crowd Out Private Capital?", Journal of Monetary Economics 23, 434-456.

[3] - (1995), "Infrastructure and Macroeconomic Performance: Direct and Indirect Effects", 85-101, in: The OECD Jobs Study: Investment, Productivity and Employment, OECD, Paris.

[4] - (2000), "Do States Optimize? Public Capital and Economic Growth", Annals of Regional Science 34, 343-363. 
[5] Becker, Gary S. (1983), "A Theory of Competition Among Pressure Groups for Political Influence"; Quarterly Journal of Economics 98, 371-400.

[6] Bergemann, Dirk, and Juuso Valimaki (1999), "Dynamic Common Agency"; Kellog Graduate School of Management working paper 1259.

[7] Bernheim, Douglas, and Michael Whinston (1986a), "Menu Auctions, Resource Allocation, and Economic Influence", The Quarterly Journal of Economics 101, 1-31.

[8] — (1986b), "Common Agency", Econometrica 54, 923-942.

[9] Besley, Tim and S. Coate (1998), "Sources of Inefficiency in a Representative Democracy: A Dynamic Analysis"; American Economic Review 88.

[10] - and - (2001), "Lobbying and Welfare in a Representative Democracy"; Review of Economic Studies 68, 67-82.

[11] — and Robin Burgess (2001), “The Political Economy of Government Responsiveness: Theory and Evidence from India"; CEPR DP 2721.

[12] — and M. Ghatak (2001), “Government vs. Private Ownership of Public Goods”, CEPR discussion paper 2725 .

[13] Bihr, Alain (1991), “Les enseignements politiques de l'analyse sociologique de l'électorat du Front National", Celsius 40, 3-10.

[14] Borraz, Olivier, and Jean-Pierre Worms (1996), "Dysfonctionnement du Pouvoir Local", Projet 245.

[15] de Closets, Francois (1992), Tant et Plus, Grasset.

[16] Chiche, Jean, and H. Rey (1995), "Le Vote des banlieues", Politis, June-August.

[17] Combes, Pierre-Philippe, and M. Lafourcade (2001), “Transport Cost Decline and Regional Inequalities: Evidence from France", CEPR discussion paper 2894.

[18] Crain, W.M., and L.K. Oakley (1995), "The politics of Infrastructure", Journal of Law and Economics 38, 1-18.

[19] Dixit, Avinash (1996), The Making of Economic Policy: A Transaction-Cost Politics Perspective, MIT press. 
[20] Dixit, Avinash, Gene Grossman and Elhanan Helpman (1997), “Common Agency and Coordination: General Theory and Application to Government Policymaking" Journal of Political Economy 105, 752-769.

[21] Drazen, Allan (2000), Political Economy in Macroeconomics; Princeton University Press.

[22] Duffy-Deno, K.T., and Eberts, Randall W. (1991), "Public Infrastructure and Regional Economic Development: A Simultaneous Equation Approach", Journal of Urban Ecocomics, 30, 329-343.

[23] Eberts, Randall W. (1990), "Public Infrastructure and Regional Economic Development", Federal Reserve Bank of Cleveland Economic Review 26, 15-27.

[24] Eisner, R. (1991), "Infrastructure and Regional Economic Performance"; New England Economic Review, Federal Res. Bank of Boston, Sept./Oct., 47-58.

[25] Etchegoyen, Alain (1995), Corrupteur et Corrompu; Julliard.

[26] de la Fuente, Angel., and X. Vives (1995), “Education, Infrastructure and Regional Inequality: Evidence from Spain "; Economic Policy 20, 13-51.

[27] Flores de Frutos, R. and Pereira, A. M. M. (1993), "Public Capital and Aggregate Growth in the United States: Is Public Capital Productive?", W 562 (93, 31), University of California Discussion Paper.

[28] Franceries, Franck (1993), “Des Votes aveugles: l'exemple des electeurs FN en milieu populaire", Politix 22, 119-137.

[29] Fritsch, B., and R. Prud'homme (1994), "Measuring the Contribution of Road Infrastructure to Economic Development in France", Université Paris XII, working paper 94-02.

[30] Godfrey, L. G. (1988), Misspecification tests in econometrics: the Lagrange multiplier principle and other approaches, Cambridge University Press.

[31] Gramlich, E. M. (1990), A Guide to Benefit-Cost Analysis, 2nd ed., Prentice-Hall.

[32] - (1994), "Infrastructure Investment: A Review Essay", Journal of Economic Literature 32, 1176-1196.

[33] Greene, William H. (1997), Econometric Analysis, 3rd ed., New York, Macmillian. 
[34] Grossman, Gene M. and Elhanan Helpman (1994), "Protection for Sale", The American Economic Review 84, 833-850.

[35] Henze, N. and Zirkler, B. (1990), “A Class of Invariant Consistent Tests for Multivariate Normality", Comm.Statist.-Theory Meth. 19, 3595-3617.

[36] Holtz-Eakin, Douglas (1988), "Private Output, Government Capital, and the Infrastructure 'Crisis'; Columbia University Discussion paper 394.

[37] - (1994), "Public-sector Capital and the Productivity Puzzle"; Review of Economics and Statistics 76, 12-21.

[38] Hulten, C. (1995), “Infrastructure Spending: Where Do We Go from Here?", Proceedings of the National Tax Association conference, 1995.

[39] Kaizuka, K. (1965), "Public Goods and Decentralization of Production"; Review of Economics and Statistics 30, 118-120.

[40] Laguarrigue, F., (1994), "Infrastructures de Transport et Croissance Endogène", mimeo, OEST, Ministère de l'Equipement, des Transports et du Tourisme.

[41] Lizzeri, Alessandro, and N. Persico (2001), “The Provision of Public Goods Under Alternative Electoral Incentives", American Economic Review 91, 225-239.

[42] Lorenzi, Pierre-Antoine (1995), Corruption et Imposture, Balland.

[43] Martin, Philippe, and Carol A. Rogers (1995), "Industrial Location and Public Infrastructure"; Journal of International Economics 39, 335-351.

[44] — (1999), "Public Policies, Regional Inequalities and Growth"; Journal of Public Economics 73, 85-105.

[45] Mayer, Nonna, and P. Perrineau, eds. (1996), Le Front National à Découvert, Presses de Sciences Po.

[46] Mény, Yves (1992), La Corruption de la République; Fayard.

[47] Morrison, Catherine, and A. Schwartz (1996), "State Infrastructure and Productive Performance", American Economic Review 86, PAGES? 
[48] Munnell, Alicia H. (1990a), “Why has Productivity Growth Declined? Productivity and Public Investment", New England Economic Review, Jan / Feb, 3-22.

[49] — (1990b), "How Does Public Infrastructure Affect Regional Economic performance?" in A. Munnell, ed., Is There a Shortfall in Public Capital Investment? Boston: Federal Reserve Bank of Boston.

[50] Negishi, Takashi (1973), "The Excess of Public Expenditures on Industries"; Journal of Public Economics 2, 231-240.

[51] Peterson, G. E. (1991), “Historical Perspective on Infrastructure Investment: How Did We Get Where We Are?", American Enterprise Institute Discussion Paper.

[52] Sandmo, Agnar (1972), “Optimality Rules for the Provision of Collective Factors of Production"; Journal of Public Economics 1, 149-157.

[53] Service Central de Prevention de la Corruption (1994), Rapport Annuel 1993/94, Paris.

[54] Tatom, J. A. (1993), "Paved with Good Intentions: The Mythical National Infrastructure Crisis", Washington, DC: Cato Institute.

[55] US Congressional Budget Office (1988), New Directions for the nation's public works, Washington, DC: US GPO, 1988.

[56] White, Kenneth J. (1992), “The Durbin-Watson Test for Autocorrelation in Non-Linear Models", The Review of Economics and Statistics, 74, 370-373.

[57] Wittman, Donald (1983), "Candidate Motivations: A Synthesis of Alternatives"; American Political Science Review 77, 142-157. 
Table 1: Variable Description and Regions

\begin{tabular}{lll}
\hline Variable & Description \\
\hline VA & Regional GDP, million 1992 Francs \\
$E M P$ & Regional employment, million individuals \\
CAP & Non-residential private capital stock, million 1992 Francs \\
$I N F R A S T$ & Transportation infrastructure stock, million 1992 Francs \\
$I N V$ & Transportation infrastructure net investments, million 1992 Francs \\
LARGE & Number of establishments with more than 500 employees \\
PARTY & Dummy =1 when local/national political congruence \\
DIFF & Absolute value of RW score minus LW score, in percent. points \\
LEPEN & Front National + hunters' party combined scores, in percent. points \\
$I N C U M B$ & Incumbent's margin, in percent. points \\
Regions & & \\
Alsace & Champagne-Ardennes & Midi-Pyrenées \\
Aquitaine & Franche-Comté & Nord-Pas de Calais \\
Auvergne & Haute-Normandie & Pays de Loire \\
Basse-Normandie & Ile-de-France & Picardie \\
Bourgogne & Languedoc-Roussillon & Poitou-Charentes \\
Bretagne & Limousin & Provence-Alpes-Côte d'Azur \\
Centre & Lorraine & Rhône-Alpes \\
\hline
\end{tabular}

Table 2: Summary Statistics

\begin{tabular}{|c|c|c|c|c|}
\hline Variable & Mean & St. Dev. & Minimum & Maximum \\
\hline$\overline{V A / E M P}$ & 256723 & 27380.40 & 195921 & 357617 \\
\hline CAP/EMP & 298142 & 62624.98 & 188442 & 484980 \\
\hline INFRAST / EMP & 50920 & 9412.91 & 35453 & 70935 \\
\hline VA/INFRAST & 5.166 & 0.8416 & 3.849 & 7.405 \\
\hline$I N V / E M P$ & 1396 & 628.15 & 412 & 4934 \\
\hline$L A R G E$ & 35.27 & 21.66 & 5 & 113 \\
\hline$L A R G E / \ell$ & 42.62 & 17.56 & 11.90 & 79.64 \\
\hline DIFF & 6.94 & 5.404 & 0.03 & 35.10 \\
\hline INCUMB & 5.42 & 6.824 & -14.50 & 26.6 \\
\hline LEPEN & 13.9 & 6.239 & 3.40 & 26.6 \\
\hline$X_{\text {HIGHWAY }} / X$ & 5.1 & 2.36 & 1.74 & 13.68 \\
\hline$X_{\text {HIGHWAY }} / X_{\text {WATER }}$ & 68.8 & 80.17 & 2.27 & 2.90 \\
\hline
\end{tabular}


Table 3: Estimation Results

\begin{tabular}{ccccccc}
\hline & \multicolumn{2}{c}{ OLS } & \multicolumn{2}{c}{ FIML } & \multicolumn{2}{c}{ FIML } \\
Variable & estimate & t-stat & estimate & t-stat & estimate & t-stat \\
\hline Production function: & Dependent & Variable & $\ln (V A / E M P)$ & & \\
85 & 3.940 & 21.21 & 3.905 & 21.95 & 3.919 & 22.04 \\
86 & 3.969 & 21.33 & 3.934 & 22.07 & 3.948 & 22.16 \\
87 & 3.985 & 21.34 & 3.950 & 22.09 & 3.964 & 22.18 \\
88 & 4.003 & 21.32 & 3.967 & 22.07 & 3.981 & 22.15 \\
89 & 4.021 & 21.29 & 3.985 & 22.04 & 3.999 & 22.12 \\
90 & 4.013 & 21.19 & 3.977 & 21.93 & 3.991 & 22.01 \\
91 & 4.011 & 21.05 & 3.975 & 21.79 & 3.989 & 21.87 \\
92 & 4.027 & 21.03 & 3.991 & 21.77 & 4.005 & 21.85 \\
CAP/EMP & 0.182 & 5.26 & 0.186 & 5.59 & 0.182 & 5.50 \\
EMP & 0.029 & 1.84 & 0.030 & 1.96 & 0.028 & 1.87 \\
INFRAST /EMP & 0.080 & 1.90 & 0.083 & 2.06 & 0.086 & 2.16 \\
PARIS & 0.214 & 4.95 & 0.217 & 5.20 & 0.219 & 5.27 \\
AR(1) & 0.888 & 0.888 & 0.888 & \\
Godfrey LM Test & 1.949 & 1.999 & 1.982 & \\
White Test & 37.05 & 36.81 & 37.14 & \\
R $^{2}$ & 0.9575 & 0.9577 & 0.9576
\end{tabular}

Policy function: Dependent Variable INV / EMP

\begin{tabular}{|c|c|c|c|c|c|c|}
\hline \multicolumn{7}{|l|}{ Variable } \\
\hline 85 & 2416.68 & 6.27 & 2579.74 & 7.06 & 3200.21 & 9.74 \\
\hline 86 & 2452.16 & 6.26 & 2616.15 & 7.05 & 3237.91 & 9.69 \\
\hline 87 & 2437.17 & 5.94 & 2599.92 & 6.71 & 3239.32 & 9.18 \\
\hline 88 & 2663.08 & 6.36 & 2833.54 & 7.16 & 3473.72 & 9.56 \\
\hline 89 & 2867.94 & 6.97 & 3055.73 & 7.81 & 3676.67 & 10.12 \\
\hline 90 & 2701.02 & 6.49 & 2892.57 & 7.31 & 3508.87 & 9.48 \\
\hline 91 & 2821.59 & 6.83 & 3016.82 & 7.66 & 3625.54 & 9.77 \\
\hline 92 & 2655.02 & 6.38 & 2853.97 & 7.19 & 3459.01 & 9.18 \\
\hline$\alpha_{x} V A / I N F R A S T$ & -1792.84 & -1.43 & -2107.62 & -1.73 & -2607.13 & -1.95 \\
\hline PARTY & 117.17 & 1.50 & 130.43 & 1.79 & 95.31 & 1.33 \\
\hline$D I F F$ & -34.62 & -2.55 & -32.70 & -2.58 & -38.83 & -3.73 \\
\hline LEPEN & 29.31 & 3.26 & 25.93 & 3.07 & 21.72 & 2.63 \\
\hline LARGE & 8.25 & 3.87 & 8.63 & 4.39 & - & - \\
\hline INCUMB & 26.26 & 2.29 & 25.65 & 2.42 & - & - \\
\hline INCUMB * LARGE & - & - & - & - & 0.91 & 5.73 \\
\hline TGVCENTRE & 1096.46 & 5.42 & 1139.09 & 6.03 & 1172.25 & 6.23 \\
\hline TGVNORD & 3112.54 & 11.21 & 3124.73 & 12.06 & 3230.35 & 12.75 \\
\hline PARIS & -619.28 & -1.78 & -608.64 & -1.89 & 2.41 & 0.01 \\
\hline$A R(1)$ & 0.49 & & 0.48 & & 0.4 & \\
\hline Godfrey LM Test & 1.19 & & 2.01 & & 1.7 & \\
\hline White Test & 118. & & 116. & & 107 & \\
\hline $\mathrm{R}^{2}$ & 0.87 & & 0.87 & & 0.87 & \\
\hline Henze-Zirkler $T$ & 2.1 & & 2.0 & & 1.7 & \\
\hline
\end{tabular}



Bücher des Forschungsschwerpunkts Markt und politische Ökonomie

Books of the Research Area Markets and Political Economy

Andreas Stephan

Essays on the Contribution of Public Infrastructure to Private: Production and its Political

Economy

2002, dissertation.de

Hans Mewis

Essays on Herd Behavior and Strategic

Delegation

2001, Shaker Verlag

Andreas Moerke

Organisationslernen über Netzwerke - Die

personellen Verflechtungen von

Führungsgremien japanischer

Aktiengesellschaften

2001, Deutscher Universitäts-Verlag

Silke Neubauer

Multimarket Contact and Organizational Design

2001, Deutscher Universitäts-Verlag

Lars-Hendrik Röller, Christian Wey (Eds.)

Die Soziale Marktwirtschaft in der neuen

Weltwirtschaft, WZB Jahrbuch 2001

2001, edition sigma

Michael Tröge

Competition in Credit Markets: A Theoretic

Analysis

2001, Deutscher Universitäts-Verlag

Tobias Miarka

Financial Intermediation and Deregulation:

A Critical Analysis of Japanese Bank-Firm-

Relationships

2000, Physica-Verlag

Damien J. Neven, Lars-Hendrik Röller (Eds.)

The Political Economy of Industrial Policy in

Europe and the Member States

2000, edition sigma

Jianping Yang

Bankbeziehungen deutscher Unternehmen: Investitionsverhalten und Risikoanalyse

2000, Deutscher Universitäts-Verlag

Horst Albach, Ulrike Görtzen, Rita Zobel (Eds.)

Information Processing as a Competitive

Advantage of Japanese Firms

1999, edition sigma

Dieter Köster

Wettbewerb in Netzproduktmärkten

1999, Deutscher Universitäts-Verlag

Christian Wey

Marktorganisation durch Standardisierung: Ein

Beitrag zur Neuen Institutionenökonomik des

Marktes

1999, edition sigma
Horst Albach, Meinolf Dierkes, Ariane Berthoin Antal,

Kristina Vaillant (Hg.)

Organisationslernen - institutionelle und

kulturelle Dimensionen

WZB-Jahrbuch 1998

1998, edition sigma

Lars Bergman, Chris Doyle, Jordi Gual, Lars

Hultkrantz, Damien Neven, Lars-Hendrik Röller,

Leonard Waverman

Europe's Network Industries: Conflicting

Priorities - Telecommunications

Monitoring European Deregulation 1

1998, Centre for Economic Policy Research

Manfred Fleischer

The Inefficiency Trap

Strategy Failure in the

German Machine Tool Industry

1997, edition sigma

Christian Göseke

Information Gathering and Dissemination

The Contribution of JETRO to

Japanese Competitiveness

1997, Deutscher Universitäts-Verlag

Andreas Schmidt

Flugzeughersteller zwischen globalem

Wettbewerb und internationaler Kooperation

Der Einfluß von Organisationsstrukturen auf die

Wettbewerbsfähigkeit von Hochtechnologie-

Unternehmen

1997, edition sigma

Horst Albach, Jim Y. Jin, Christoph Schenk (Eds.)

Collusion through Information Sharing?

New Trends in Competition Policy

1996, edition sigma

Stefan O. Georg

Die Leistungsfähigkeit japanischer Banken

Eine Strukturanalyse des Bankensystems in

Japan

1996, edition sigma

Stephanie Rosenkranz

Cooperation for Product Innovation

1996, edition sigma

Horst Albach, Stephanie Rosenkranz (Eds.)

Intellectual Property Rights and Global

Competition - Towards a New Synthesis

1995, edition sigma

David B. Audretsch

Innovation and Industry Evolution

1995, The MIT Press 
Julie Ann Elston

US Tax Reform and Investment: Reality and Rhetoric in the 1980s

1995, Avebury
Horst Albach

The Transformation of Firms and Markets:

A Network Approach to Economic Transformation Processes in East Germany

Acta Universitatis Upsaliensis, Studia Oeconomiae Negotiorum, Vol. 34

1994, Almqvist \& Wiksell International (Stockholm) 
Fredrik Andersson

Kai A. Konrad

Andreas Stephan

Tomaso Duso

Steffen Huck

Kai A. Konrad

Wieland Müller

Steffen Huck

Kai A. Konrad

Wieland Müller

Jos Jansen

Astrid Jung

Jonas Björnerstedt Johan Stennek

Manfred Fleischer

Karl Wärneryd

Karl Wärneryd

Steffen Huck

Kai A. Konrad

Michal Grajek

Achim Kemmerling

Andreas Stephan

Suchan Chae

Paul Heidhues

Kai A. Konrad Harald Künemund Kjell Erik Lommerud Julio R. Robledo

Tomaso Duso Lars-Hendrik Röller
Globalization and Human Capital Formation

FS IV $01-01$

Regional Infrastructure Policy and its Impact

FS IV $01-02$ on Productivity: A Comparison of Germany and France

Lobbying and Regulation in a Political Economy: FS IV $01-03$ Evidence from the US Cellular Industry

Merger and Collusion in Contest

FS IV $01-04$

Profitable Horizontal Mergers without Cost

Advantages: The Role of Internal Organization,

Information, and Market Structure

Strategic Information Revelation and Revenue

Sharing in an R\&D Race

(A revision of FS IV 99-11)

FS IV $01-05$

FS IV $01-06$

FS IV $01-07$

Complements?

Bilateral Oligopoly

FS IV $01-08$

Regulierungswettbewerb und Innovation in der chemischen Industrie

FS IV $01-09$

FS IV $01-10$

Preference Adaptation in Winner-Take-All Markets

Information in Conflicts

FS IV $01-11$

FS IV $01-12$

Merger Profitability and Trade Policy

Gender Pay Gap in Poland

FS IV $01-13$

FS IV $01-14$

The Contribution of Local Public Infra-structure to Private Productivity and its Political-Economy: Evidence from a Panel of Large German Cities

Nash Bargaining Solution with Coalitions and the Joint Bargaining Paradox

Geography of the Family

FS IV $01-15$

FS IV $01-16$

Towards a Political Economy of Industrial OrganFS IV $01-17$ ization: Empirical Regularities from Deregulation 
Kai A. Konrad

Roman Inderst Christian Wey

Kai A. Konrad

Helmut Seitz

Klaus Gugler Dennis C. Mueller B. Burcin Yurtoglu Christine Zulehner

Kjell Erik Lommerud Odd Rune Straume Lars Sørgard

Andreas Blume Paul Heidhues

Roman Inders Christian Wey

Klaus Gugler Dennis C. Mueller B. Burcin Yurtoglu

Sven-Olof Fridolfsson Johan Stennek
Investment in the Absence of Property Rights - The Role of Incumbency Advantages

Bargaining, Mergers, and Technology Choice in Bilaterally Oligopolistic Industries

Fiscal Federalism and Risk Sharing in Germany: The Role of Size Differences

The Effects of Mergers: An International Comparison

Downstream Merger with Oligopolistic Input FS IV 01-22 Suppliers

Tacit Collusion in Repeated Auctions

The Incentives for Takeover in Oligopoly

Corporate Governance, Capital Market Discipline and the Returns on Investment

Why Mergers Reduce Profits and Raise Share Prices: A Theory of Preemptive Mergers
FS IV $01-23$

FS IV $01-24$

FS IV $01-18$

FS IV $01-19$

FS IV $01-20$

FS IV $01-21$

FS IV $01-25$

FS IV $01-26$ 
Fredrik Andersson Kai A. Konrad

Lars-Hendrik Röller

Christian Wey

Talat Mahmood Klaus Schömann

Jos Jansen

Jos Jansen

Günter Franke Harris Schlesinger Richard C. Stapleton

Tomaso Duso

Johan Lagerlöf

Paul Heidhues

Olivier Cadot Lars-Hendrik Röller Andreas Stephan
Human Capital Investment and Globalization in Extortionary States

Merger Control in the New Economy

Die Determinanten der Mirgrationsentscheidung von IT-Hochschulabsolventen aus Pakistan Empirische Befunde zur Ausgestaltung der deutschen „Green Card“"

The Effects of Disclosure Regulation on Innovative Firms: Common Values

The Effects of Disclosure Regulation on Innovative Firms: Private Values

Multiplicative Background Risk

On the Politics of the Regulatory Reform: Econometric Evidence from the OECD Countries

On the Desirability of an Efficiency Defense in Merger Control

Contribution to Productivity or Pork Barrel? The Two Faces of Infrastructure Investment
FS IV $02-02$

FS IV $02-06$

FS IV $02-07$

FS IV $02-01$

FS IV $02-03$

FS IV $02-04$

FS IV $02-05$

FS IV $02-08$

FS IV $02-09$ 

Bei Ihren Bestellungen von WZB-Papers schicken

Sie bitte unbedingt einen an Sie adressierten Auf-

kleber mit sowie je paper eine Briefmarke im Wert

von 0,51 Euro oder einen "Coupon Reponse Inter-

national " (für Besteller aus dem Ausland)
Please send a self addressed label and postage stamps in the amount of 0.51 Euro or a "CouponReponse International" (if you are ordering from outside Germany) for each WZB-paper requested

Absender / Return Address:

Wissenschaftszentrum Berlin

für Sozialforschung

Presse- und informationsreferat

Reichpietschufer 50

D-10785 Berlin-Tiergarten

Hiermit bestelle ich folgende(s)

Discussion paper(s):

Please send me the following Discussion paper(s):

Bestell-Nr. / Order no.

Autor/in, Kurztitel /Author(s) / Title(s) in brief 